Hanaba Dmytro. Greening of the City Khmelnitsky in the Second Half of the Twentieth Century. The article discusses the features of greening urban infrastructure of Khmelnytskyi in the second half of the twentieth century. It is noted that the relevance and importance of this problem stems from the needs of creating a sustainable urboekological system, improvement of sanitary and hygienic conditions and comfortable aesthetic rest of the people in the city. Based on the analysis of documents city municipal department analyzed greening the city . Specified the magnitude of a complex of actions on gardening, was carried out on the basis of party and government programmes. The feature of landscaping Khmelnitsky which survived and till nowadays is a connection with national holidays and anniversaries.

A positive factor in the process of landscaping was the involvement of the public in planting large number of trees and shrubs and care for young plantings. The practice of using the efforts of the public in plant conservation and increase the number and range of parks, squares and streets should be considered in future plans for landscaping. The characteristic deficiency in the process of gardening that becomes a deepening, and still is unsystematic in choosing the variety of plants, a small variety of their species composition, the lack of a scientific approach to the landscaping projects of the city. In the process of landscaping were hardly taken into account the climatic characteristics of the urban area, sanitary conditions and environmental features of the urban environment.

Key words: tree planting, landscaping, urboecological system, a set of measures, methods, plants.

Стаття надійшла до редколегії 14.09.2016 р.

Інна Зубцова

\title{
Онтогенетична структура ценопопуляцій Polygonum Aviculare L. в умовах Кролевецько-Глухівського геоботанічного району
}

У статті наведено онтогенетичну характеристику ценопопуляцій Polygonum aviculare L. на луках Кролевецько-Глухівського геоботанічного району. Розраховано індекс віковості за А. А. Урановим $(\Delta)$ та індекс ефективності за Л. В. Животовським $(\omega)$. Визначено належність кожної з досліджених ценопопуляцій до певної категорії, згідно з класифікацією Т. О. Работнова (інвазійні, нормальні, регресивні), Л. В. Животовського (молоді, перехідні, зріючі, зрілі, старіючі, старі). Побудовано та проаналізовано онтогенетичні спектри ценопопуляцій P. aviculare в аспекті їх належності до одного з типів: лівобічні, центровані, правобічні. Визначено частку рослин різних онтогенетичних станів у шести популяцій $P$. aviculare. На основі отриманих результатів зроблено висновки про онтогенетичну структуру ценопопуляцій $P$. aviculare в умовах досліджуваного району.

Ключові слова: Кролевецько-Глухівський геоботанічний район, Polygonum aviculare L., онтогенетичні спектри, онтогенетична структура, фітопопуляції.

Постановка наукової проблеми та ії значення. У наш час, незважаючи на неймовірні досягнення у сфері синтезу лікарських препаратів, використання лікарських рослин не лише не знижується, а навпаки - суттєво зростає [12]. Висока ефективність лікарських рослин визначається наявністю в органах рослин біологічно активних речовин, які, діючи на ті чи інші органи людини, викликають терапевтичний ефект. Перевагою лікарських рослин $є$ їхня мала токсичність і можливість довготривалого прийому без істотних побічних наслідків.

Однак заготівля лікарської сировини часто супроводжується цілеспрямованим вилученням зі складу фітоценозів особин, найцінніших за життєвістю, онтогенетичними показниками. Це суттєво зменшує здатність ценопопуляцій до сталого та довготривалого існування. Для запобігання таким явищам потрібне поглиблене вивчення стану ценопопуляцій лікарських видів рослин [13]. Один із таких ефективних методів - аналіз онтогенетичної структури ценопопуляцій. Біля його витоків стояли такі геоботаніки, як Т. О. Работнов [11] та О. О. Уранов [14; 15]. Також свій внесок у вивчення популяцій на основі популяційно-онтогенетичного підходу зробили О. В. Смирнова, Л. Б. Заугольнова [16; 17].

Зважаючи на зазначене вище, вивчення онтогенетичних характеристик ценопопуляцій дикорослих лікарських рослин уважаємо актуальною науковою проблемою. В Україні одним з осередків

(C) Зубичова I., 2016 
ïx зростання $\epsilon$ Кролевецько-Глухівський геоботанічний район [1], зокрема його лучні угруповання. Для зазначеного регіону до найпоширеніших видів лікарських рослин належить спориш звичайний (Polygonum aviculare L.), який і був об'єктом наших досліджень.

Аналіз досліджень цісї проблеми. Відомості про онтогенез та онтогенетичну структуру P. aviculare в літературних джерелах майже відсутні, хоча популяції низки інших лікарських рослин достатньо досліджено. Таку інформацію наведено в роботах Л. А. Жукової (1996) Н. П. Грошевої, О. Л. Воскресенської (1998); Т. К. Головко (1999); О. А. Скочилової (2000); І. С. Тетерина, (2001); Н. Н. Редькіної (2013) та ін. [3; 7; 13].

Мета й завдання статті. Мета публікації - розкрити онтогенетичну структуру ценопопуляцій P. aviculare.

Завдання дослідження - визначити частку рослин різних онтогенетичних станів у шести популяцій $P$. aviculare, що зростають на луках Кролевецько-Глухівського геоботанічного району; проаналізувати онтогенетичні спектри ценопопуляцій $P$. aviculare в аспекті їх належності до одного 3 типів: лівобічні, центровані, правобічні; розрахувати індекс віковості та індекс ефективності популяцій; визначити належність кожної з досліджених ценопопуляцій до певної категорії згідно 3 класифікацією Т. О. Работнова й Л. А. Животовського.

Виклад основного матеріалу й обгрунтування отриманих результатів дослідження. Матеріал для вивчення онтогенетичної структури $P$. aviculare зібрано на заплавних луках КролевецькоГлухівського геоботанічного району в третій декаді липня 2015-2016 рр. Опис рослинних угруповань, де зростає $P$. aviculare, проводили згідно із загальноприйнятими геоботанічними методами [8; 10].

Онтогенетичну структуру ценопопуляцій $P$. aviculare досліджено в шести лучних фітоценозах. При цьому місцезростання двох ценопопуляцій не зазнавали суттєвої антропогенної дії (ЦП 5 с. Слоут та ЦП 6 - с. Береза Глухівського району). Чотири інші, навпаки, перебували під впливом антропопресії. Це були випас (ЦП 3 - с. Сварково, ЦП 4 - с. Білокопитове Глухівського р-ну) і випалювання (ЦП 1 - с. Чернєво та ЦП 2 - с. Заруцьке Глухівського р-ну). Усі досліджувані ценопопуляції зростали в моновидових фітоценозах, у яких проективне покриття P. aviculare сягало 90-95\%.

Для визначення онтогенетичної структури в досліджуваних угрупованнях за випадковою системою розміщували 40-60 облікових ділянок розміром $0,25 \mathrm{~m}^{2}$, на яких оцінювали кількість рослин $P$. aviculare різних онтогенетичних станів [5; 6; 9]. Визначення онтогенетичних параметрів ценопопуляцій цього виду здійснювали з опорою на такі показники й характеристики:

- за класифікацією Т. О. Работнова визначено належність кожної ценопопуляції до певної категорії (інвазійні - популяції, у складі яких переважають пререпродуктивні особини, нормальні - у них переважають репродуктивні рослини, регресивні - надмірно пострепродуктивні особини);

- за методикою О. О. Уранова визначено індекс віковості $(\Delta)$;

- за методикою Л. А. Животовського ( $\omega)$ установлено індекс ефективності [2];

- за співвідношенням величин $\Delta / \omega$ визначено належність ценопопуляцій $P$. aviculare до певної категорії. При цьому спиралися на таку градацію величин:

- молоді ценопопуляції: $\Delta<0,35, \omega<0,60$;

- перехідні: $\Delta>0,35$, але <0,55, $\omega<0,70$;

- зріючі: $\Delta<0,35, \omega>0,60$

- зрілі: $\Delta>0,35$, але < $0,55, \omega>0,70$;

- старіючі: $\Delta>0,55, \omega>0,60$;

- старі: $\Delta>0,55, \omega<0,60$.

Усі розрахунки індексів здійснювали за допомогою спеціалізованого, некомерційного програмного комплексу ANONS 6, розробленого Ю. А. Злобіним [5].

За умови відсутності методик щодо визначення належності $P$. aviculare до певних онтогенетичних періодів нами проведено дослідження, спрямовані на установлення характеристик рослин різних онтогенетичних станів. При цьому враховували морфологічні ознаки надземних і підземних органів особин цього виду. Для P. aviculare нами описано три періоди та дев'ять онтогенетичних станів.

Пререпродуктивний період

ПРОРОСТКИ (р): рослини мають розгалужене від основи стебло з циліндричними міжвузлями, довжина якого становить 1-4 см. Діаметр стебла не перевищує 0,2 мм і на ньому розміщується не більше двох листків. У цих особин $є$ зародковий корінь із тонкими білими бічними корінцями (рис. 1). 
ЮВЕНІЛЬНІ (j): молоді рослини, які вже не мають зародкового кореня. Стебло довжиною до 6 см, колінчасте. Кількість листків переважно варіює від 5 до 7 шт. Коренева система стрижнева.

IMMAТУРНI (im): рослини формують незначно розгалужене стебло довжиною до 8-9 см та діаметром 0,4 мм. Листки прості, зверху голі, їхня кількість здебільшого становить 9-13 шт. Головний корінь тонкий, дещо довший, ніж у ювенільних.

ВІРГІНІЛЬНІ (v): особини мають розгалужене від основи стебло, здебільшого лежаче, довжиною до 10-15 см. Листки прості, короткочерешкові, почергові, зазвичай у кількості 14-17 шт. Корінь довгий, галузистий.

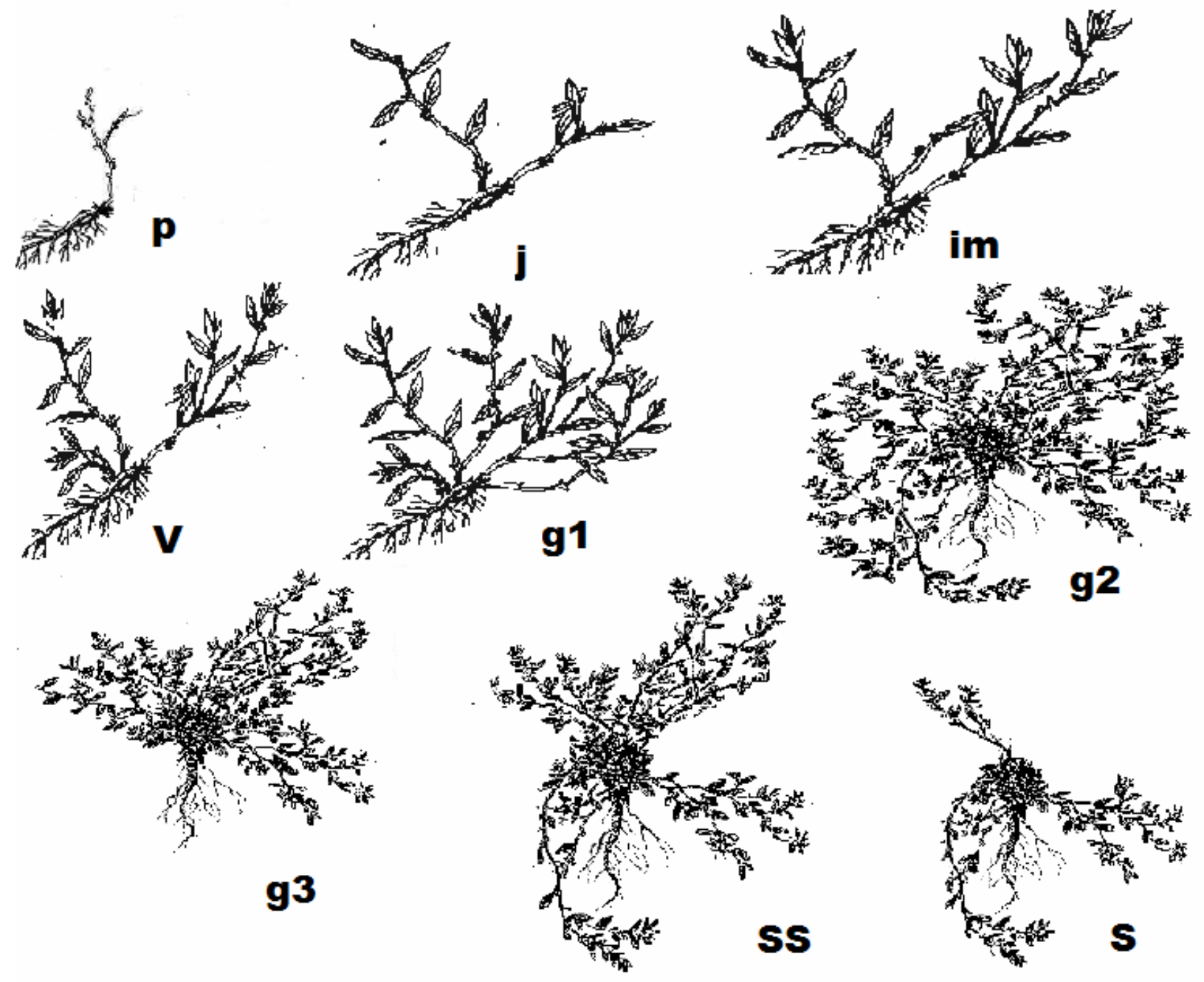

Рис. 1. Рослини Polygonит aviculare різних онтогенетичних станів: $p$ - проросток, $j$ - ювенільна, im - іматурна, v-вергінільна, $g_{1}$-молода генеративна, $g_{2}$ - середня генеративна, $g_{3}$ - стара генеративна, ss - субсенільна, s- сенільна рослини

\section{Репродуктивний період}

МОЛОДІ ГЕНЕРАТИВНІ РОСЛИНИ $\left(\mathrm{g}_{1}\right)$ мають міцне стебло довжиною до 20 см. Листки прості, короткочерешкові, почергові, здебільшого в кількості 18-25 шт. Біля основи вони утворюють чітко виражені плівчасті розтруби, різні за розмірами та формою. Квітки правильні, двостатеві, дрібні, із простою оцвітиною, зібрані по 1-5 у пазухах листків. Коренева система складається 3 довгого розгалуженого кореня.

СЕРЕДНІ ГЕНЕРАТИВНІ РОСЛИНИ $\left(\mathrm{g}_{2}\right)$ мають стебло діаметром до 1 мм. Воно розгалужене, iз циліндричними або дещо кутастими та подовжньо борозенчастими міжвузлями. Стебло вкрите 
сидячими, зверху голими листками, різними за формою й розміром. Прилистки зрослись у піхвоподібний розтруб. Дрібні пазушні квітки мають п’ять зеленувато-білих листочків оцвітини, верхівка яких - часто червоного кольору. Рослини цього онтогенетичного стану мають добре розвинену кореневу систему.

СТАРІ ГЕНЕРАТИВНІ РОСЛИНИ $\left(\mathrm{g}_{3}\right)$ формують повністю лежаче стебло з великою кількістю відмерлих листків. У цих рослин, порівняно із попереднім онтогенетичним станом, суттєво зменшується кількість квіток.

\section{Пострепродуктивний період}

СУБСЕНІЛЬНІ РОСЛИНИ (ss) вирізняються наявністю великої кількості слаборозвинених та відмерлих листків. Коренева система менш потужна. У iï складі чітко виділяється старий корінь коричневого кольору.

СЕНІЛЬНІ РОСЛИНИ (s) являють собою відмираючі особини зі слаборозгалуженим стеблом і кореневою системою.

Установлено, що досліджувані ценопуляції $P$. aviculare досить різняться за онтогенетичною структурою. Їхня характерна риса - мономодальність спектрів. ЦП 1 і ЦП 2 мають мономодальні лівобічні спектри 3 максимумом на віргінільних особинах (v). Частка цих рослин у зазначених популяціях, відповідно, становить 49,67 та 49,41 \% (табл.1). Як зазначалося Л. Б. Заугольновою [4], такий тип спектрів найбільш характерний для низки видів із простим онтогенезом.

Мономодальний центрований спектр із переважанням особин середньогенеративного стану $\left(\mathrm{g}_{2}\right)$ простежено в ЦП 3 і ЦП 4. Питома вага особин цього онтогенетичного стану коливається в межах $36,43-39,08 \%$. Мономодальний правобічний спектр із максимумом (35,25-39,69 \%) на старих генеративних особинах $\left(\mathrm{g}_{3}\right)$ зареєстровано в ЦП 5 та ЦП 6.

Отже, чотири досліджувані ценопопуляції (ЦП 3-ЦП 6) чітко вирізняються переважанням сумарної частки особин генеративного $\left(\mathrm{g}_{1}-\mathrm{g}_{3}\right)$ онтогенетичного стану (табл.1). Тобто, за трактуванням Т. А. Работнова, їх можна віднести до нормальних, яким властиві стійкість і висока здатність до самопідтримання та самовідновлення.

Таблиия 1

Онтогенетична структура ценопопуляцій Polygonum aviculare

\begin{tabular}{|c|c|c|c|c|c|c|c|c|c|}
\hline \multirow{2}{*}{ 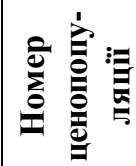 } & \multicolumn{9}{|c|}{ Онтогенетичні стани рослин та їх частка (\%) у складі угруповання } \\
\hline & $\mathrm{p}$ & $\mathrm{j}$ & $\mathrm{im}$ & $\mathrm{V}$ & $\mathrm{g}_{1}$ & $\mathrm{~g}_{2}$ & $\mathrm{~g}_{3}$ & ss & $\mathrm{s}$ \\
\hline 1 & 0,0 & 6,12 & 8,84 & 49,67 & 27,89 & 7,48 & 0,0 & 0,0 & 0,0 \\
\hline 2 & 0,0 & 7,10 & 17,65 & 49,41 & 20,55 & 5,29 & 0,0 & 0,0 & 0,0 \\
\hline 3 & 0,0 & 0,0 & 15,09 & 13,86 & 30,50 & 36,43 & 4,12 & 0,0 & 0,0 \\
\hline 4 & 0,0 & 0,0 & 8,70 & 9,94 & 28,25 & 39,08 & 14,03 & 0,0 & 0,0 \\
\hline 5 & 0,0 & 0,0 & 0,0 & 0,90 & 9,63 & 10,15 & 39,69 & 20,60 & 19,03 \\
\hline 6 & 0,0 & 0,0 & 0,0 & 0,0 & 3,89 & 14,55 & 35,25 & 28,66 & 17,65 \\
\hline
\end{tabular}

Онтогенетичні спектри всіх шести ценопопуляцій $P$. aviculare виявилися неповними за представленістю рослин різних онтогенетичних станів (рис. 2). У їхньому складі відсутні проростки. Окрім того, у ЦП 1, 2 не представлено старих генеративних, субсенільних та сенільних рослин. У складі ЦП 3, 4 не сформовані ювенільні, субсенільні й сенільні, а в ЦП 5, 6 - ювенільні та іматурні особини.

Установлено, що в досліджуваних ценопопуляцій значення індексу віковості О. О. Уранова $(\Delta)$ варіюють у межах від 0,15 до 0,54, а індексу ефективності Л. А. Животовського $(\omega)$ - від 0,40 до 1,00. Положення кожної з ценопопуляцій у просторі показників $\Delta / \omega$ представлено на рис. 3. Згідно 3 класифікацією «дельта-омега» вивчені популяції належать до трьох типів: ЦП 1, ЦП 2 - молоді, ЦП 3, ЦП 4 - зріючі, ЦП 5, ЦП 6 - зрілі. 


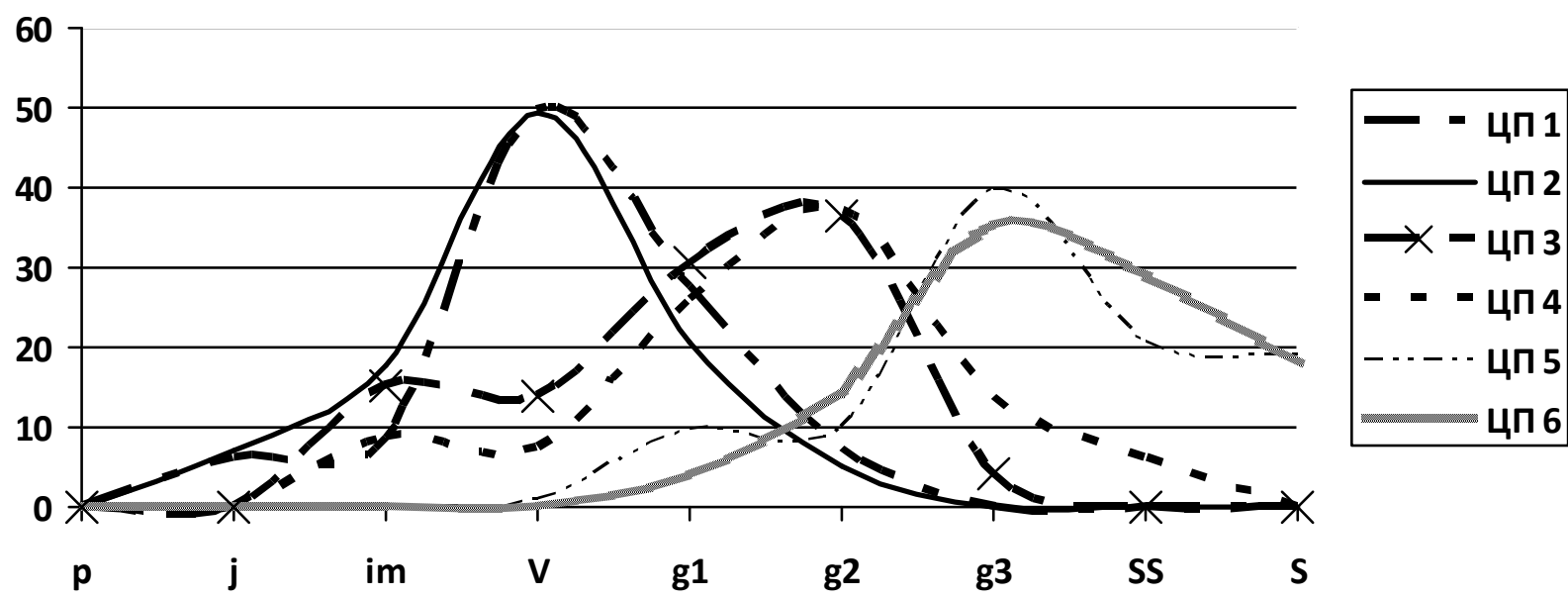

Рис. 2. Онтогенетичні спектри ценопопуляцій Polygonum aviculare

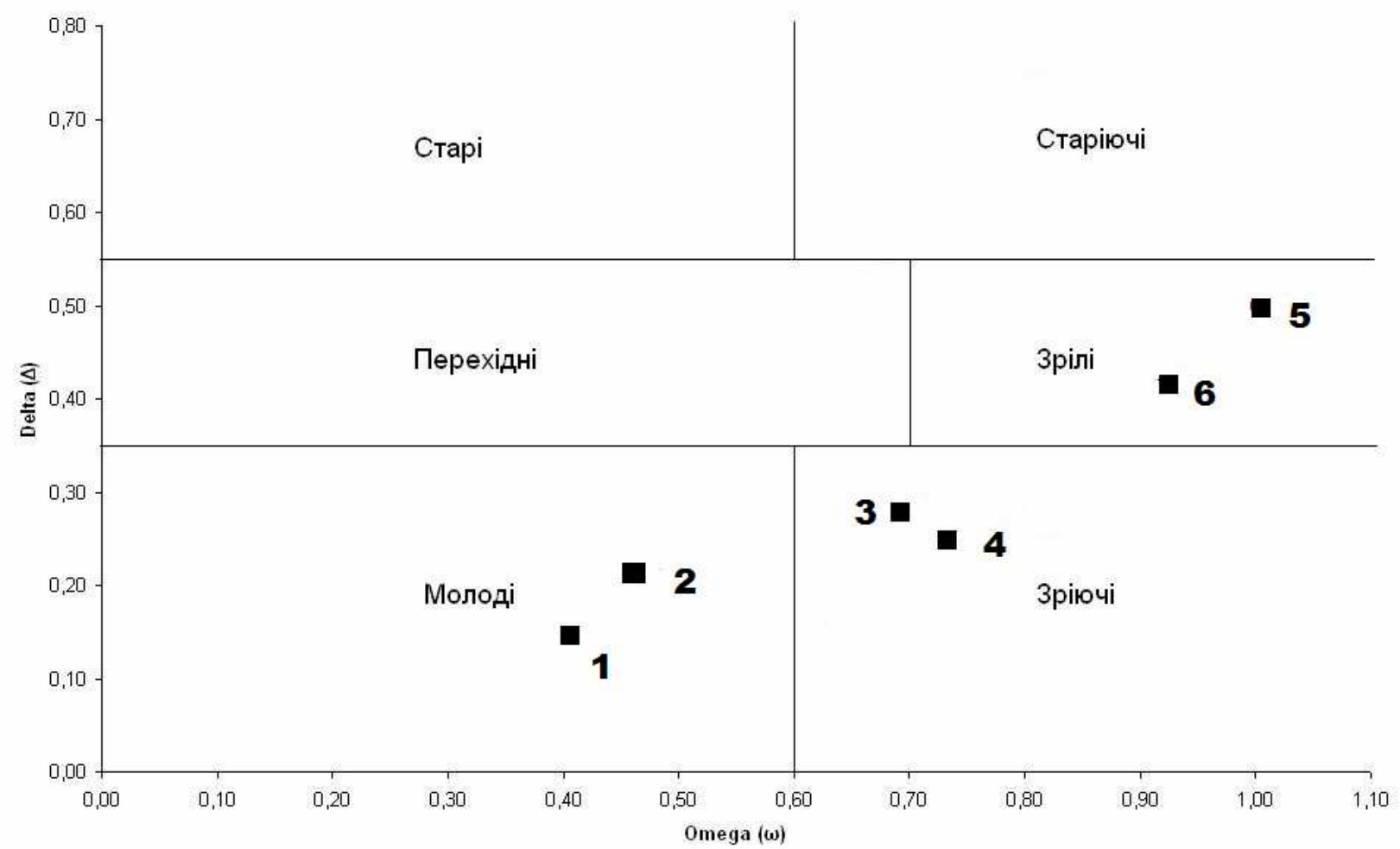

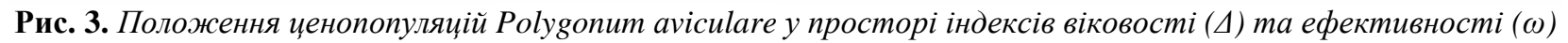

Нумерація ценопопуляцій відповідає наведеній у табл. 1.

Висновки та перспективи подальшого дослідження. У результаті дослідження онтогенезу ценопопуляцій $P$. aviculare на луках Кролевецько-Глухівського геоботанічного району в рослин цього виду виділено три періоди (пререпродуктивний, репродуктивний і пострепродуктивний) й описано дев'ять онтогенетичних станів. Характерні ознаки ценопопуляцій $P$. aviculare - неповнота та мономодальність онтогенетичних спектрів. На основі аналізу онтогенетичних спектрів зареєстровано три їх різновиди: лівобічний, центрований, правобічний.

За критерієм «дельта-омега» ценопопуляції розділилися на три типи: молоді (ЦП 1 та 2), зріючі (ЦП 3 і 4) та зрілі (ЦП 5 і 6) типи. Уважаємо, що успішний онтогенетичний розвиток рослин 
P. aviculare у ЦП 5 та 6 - результатом відсутності в цих місцезростаннях потужної антропопресії. Навпаки, антропогенний вплив (випас худоби, випалювання старої трави навесні) призвів до вповільнення онтогенетичних перетворень у ценопопуляціях ЦП 1-ЦП 4. Триваліше знаходження ЦП 1 та 2 (порівняно з ЦП 3 і 4) у типі «молодих» указує на те, що випас худоби, порівняно 3 випалюванням старої трави, чинить більш суттєвий негативний вилив на розвиток рослин і значно гальмує перехід ценопопуляцій у тип «зріючих» та «зрілих». Загалом, результати комплексного дослідження онтогенетичних характеристик ценопопуляцій $P$. aviculare свідчать про їхню досить високу здатність до стійкого існування в лучних фітоценозах Кролевецько-Глухівського геоботанічного району.

Перспективою наших подальших наукових досліджень $є$ застосування комплексного популяційного аналізу для вивчення $P$. aviculare, що дасть змогу глибше зрозуміти особливості й закономірності функціонування ценопопуляцій цього виду, а також оцінити його ресурсний потенціал у різних місцезростаннях.

\section{Джерела та література}

1. Геоботанічне районування Української РСР / [Т. Л. Андрієнко, Г. І. Білик, Є. М. Брадіс та ін.]. - К. : Наук. думка, 1977. - 302 с.

2. Животовский Л. А. Онтогенетические состояния, эффективная плотность и классификация популяций растений / Л. А. Животовский // Экология. - 2001. - № 1. - С. 3-7.

3. Жукова Л. А. Онтогенез и циклы воспроизведения растений / Л. А. Жукова // Журн. общ. биол. - 1983. T. 44, № 3. - С. 361-374.

4. Заугольнова Л. Б. Типы возрастных спектров нормальных ценопопуляций растений / Л. Б. Заугольнова // Ценопопуляции растений (основные понятия и структура). - М., 1976. - С. 81-92.

5. Злобин Ю. А. Популяции редких видов растений: теоретические основы и методика изучения : монография / Ю. А. Злобин, В. Г. Скляр, А. А. Клименко. - Сумы : Университ. кн., 2013. - 439 с.

6. Злобин Ю. А. Популяционная экология растений: современное состояние, точки роста / Ю. А. Злобин. Сумы : Университет. кн., 2009. - 263 с.

7. Критерии выделения возрастных состояний и особенности хода онтогенеза у растений различных биоморф / О. В. Смирнова, Л. Б. Заугольнова, Н. А. Торопова [и др.] // Ценопопуляции растений. - М., 1976. - C. $14-43$.

8. Методы полевого изучения лекарственных растений. - Саратов : Издат. центр «Наука», 2007. - 27 с.

9. Онтогенетический атлас лекарственных растений: научное издание / отв. ред. Л. А. Жукова. - ЙошкарОла : МарГУ, 2002. - Т. 3. -372 с

10. Полевая геоботаника : в 4 т. - М. ; Л., 1964. - Т. 3. - 530 с.

11. Работнов Т. А. Жизненный цикл многолетних травянистых растений в луговых ценозах / Т. А. Работнов // Труды БИН АН СССР. - 1950. - Сер. 3 : Геоботаника. - Вып. 6. - С. 70-204

12. Редькина Н. Н. Лекарственные растения как объект рационального использования и сохранения биологического разнообразия (на примере рода Empetrum L.) / Н. Н. Редькина. - Уфа : БГУ, 2007. - 140 с.

13. Редькина Н. Н. Изучение популяционной структуры лекарственных растений как основа разработки мер по сохранению генофонда / Н. Н. Редькина // Известия Самарского научного центра РАН. - 2008. T. 10, № 2. - С. 390.

14. Уранов А. А. Возрастной спектр фитоценопопуляций как функция времени и энергетических волновых процессов / А. А. Уранов // Биологические науки. - 1975. - № 2. - С. 7-33.

15. Уранов А. А. Онтогенез и возрастной состав популяций / А. А. Уранов // Онтогенез и возрастной состав популяций цветковых растений. - М., 1967. - С. 3-8.

16. Ценопопуляции растений (основные понятия и структура) / [О. В. Смирнова, Л. Б. Заугольнова, И. М. Ермакова и др.]. - М. : Наука,1976. - 217 с.

17. Ценопопуляции растений (очерки популяционной биологии) / [Л. Б. Заугольнова, Л. А. Жукова, А. С. Комаров, О. В. Смирнова]. - М. : Наука, 1988. - 184 с.

Зубцова Инна. Онтогенетическая структура ценопопуляций Polygonum aviculare L. в условиях Кролевецко-Глуховского геоботанического района. В статье наводится онтогенетическая характеристика ценопопуляций Polygonum aviculare L. на лугах Кролевецко-Глуховского геоботанического района. Рассчитан индекс возрастности по А. А. Уранову $(\Delta)$ и индекс эффективности по Л. В. Животовському $(\omega)$. Определена принадлежность каждой из исследованных ценопопуляций к определенной категории, согласно классификаций Т. А. Работнова (инвазионные, нормальные, регрессивные), Л. В. Животовского (молодые, переходные, зревшие, зрелые, стареющие, старые). Построены и проанализированы онтогенетические спектры ценопопуляций $P$. aviculare. Определена доля растений разных онтогенетических состояний в шести популяций $P$. aviculare. На основе 
полученных результатов сделаны выводы о онтогенетической структуре ценопопуляций P. aviculare в условиях исследуемого района.

Ключевые слова: Кролевецко-Глуховский геоботанический район, Polygonum aviculare L., онтогенетические спектры, онтогенетическая структура, фитопопуляции.

Zubtsova Inna. Ontogenetic Structure of Cenopopulations Polygonum Aviculare L. Under the Conditions of Krolevetsky-Hlukhivsky Geobotanic Region. The article presents ontogenetic structure of cenopopulations Polygonum aviculare L. on the meadows of Krolevetsky-Hlukhivsky geobotanic region. The index of age according to A. A. Uranov $(\Delta)$ and index of efficiency according to L. V. Zhyvotkovsky $(\omega)$ were calculated. Affiliation of each studied cenopopulations to a certain category is determined, according to classifications of T. O. Rabotnov (invasive, normal, regressive), L. V. Zhyvotkovsky (young, transient, maturing, mature, ageing, old). Ontogenetic spectra of cenopopulations $P$. aviculare were constructed and analyzed in the aspect of their belonging to one of the types: left-side, centered, right-side. Proportion of plants of different ontogenic states in six populations $P$. aviculare was determined. On the basis of the received results there were made conclusions on the ontogenetic structure of cenopopulations $P$. aviculare under the conditions of the studied region.

Key words: Krolevetsky-Hlukhivsky geobotanic region, polygonum aviculare 1., ontogenetic spectrum, ontogenetic structure, phytopopulation.

Стаття надійшла до редколегії 12.09.2016 р.

УДК 634.7:631.27:631.53:582:001.4

Олег Василюк, Світлана Свсікова

\section{Оцінка успішності акліматизації, характеристика біоекологічних особливостей малопоширених плодових та ягідних видів на базі Кременецького ботанічного саду}

У статті наведено результати аналізу біоекологічної структури дендрофлори. Установлено оцінку результатів успішності акліматизації на прикладі колекції малопоширених плодових і ягідних видів у Кременецькому ботанічному саду за показниками росту, генеративного розвитку та впливу екологічних факторів.

Ключові слова: колекція, екоморфа, життєва форма, ступінь акліматизації, зимостійкість, генеративний розвиток.

Постановка наукової проблеми та її значення. Вивчення, упровадження малопоширених плодових і ягідних рослин у різноманіття Кременецького горбогір'я має важливе економічне та наукове значення. Ці види $є$ цінними плодовими культурами за низкою господарських показників, а саме: відповідають вимогам сучасного плодівництва, відзначаються стійкістю до хвороб, невразливістю шкідниками, високим умістом біологічно активних речовин [1] у плодах та в інших частинах рослин, невибагливістю до грунту й агротехнікою вирощування.

У зв'язку з недостатнім вивченням адаптаційних показників видів здійснено аналіз видового складу, оцінку видів за показниками росту, генеративного розвитку, екологічними факторами. Накопичена інформація має наукове та практичне значення, що дасть можливість на теренах Кременецького ботанічного саду створити рослинну базу асортиментів плодових культур і сприяти поширенню цінних видів рослин серед садоводів нашого району.

Аналіз досліджень цієї проблеми. Вирощування рослин за межами своєї природно-географічної зони ставить їх в умови географічної невідповідності та в залежність від екологічного середовища місця зростання, що може відображатися на ефективності насіннєвого й вегетативного розмноження, визначати його здатність до самовідтворення, розвитку в умовах культури, тому комплексне вивчення цього питання актуальне для розробки наукових основ їх культивування.

Мета й завдання роботи. Відповідно до зазначеної проблеми метою досліджень було з'ясування адаптаційних показників видового різноманіття колекції та екологічної своєрідності природних об'єктів, висвітлення оцінки успішності акліматизації.

() Василюк О., Свсікова С., 2016 